\title{
Research Paper Performance of major food grains in Wardha district
}

V.O. BONDHARE, U.T. DANGORE, S.O. BONDHARE AND M.M. KADAM

ABSTRACT : The main objective of the present investigation was to study the performance for major foodgrains marketing in Wardha district. The data were collected from 120 cultivators for the year 2009-10 and secondary data were collected from various government publications for the period 1989-90 to 2008-09. The average size of family was 4 and of which male, female and children were 1,1 and 2 . The gross cropped area was 12.39 hectare which consisted of 50.92 per cent under Kharif crop, 49.08 per cent under Rabi crop. The area under wheat, tur and gram is increasing with mixed performance in production and productivity and area under jowar was shifting towards wheat, pigeonpea (tur) and chickpea (gram). Area, production and productivity of pigeonpea showed significant positive trend. Area of wheat was more or less stable and productivity of wheat was increasing as production rate was 1.92 per cent which was higher as compared to area i.e. 0.80 per cent. The decreasing trends of jowar indicated that farmers were shifting from jowar to other cash crops which are more profitable as compared to jowar. The area, production and productivity of jowar, wheat, tur and gram in Wardha district were unstable during the period of study. After harvesting of particular crop there was glut in the market means arrivals were high in the market and when arrivals are low generally the prices are high.

KEY WORDS : Performance of food grains, Pigeonpea, Chickpea, Wheat, Jowar

HOW TO CITE THIS PAPER : Bondhare, V.O., Dangore, U.T., Bondhare, S.O. and Kadam, M.M. (2014). Performance of major food grains in Wardha district, Internat. Res. J. Agric. Eco. \& Stat., 5 (2) : 170-175. 